\title{
GLOBÁLIS VERSENY A VILÁG JELENTŐS GAZDASÁGI BLOKKJAI KÖZÖTT
}

\section{(Global Competition among the Important Economic Blocks)}

\author{
MARJÁN ATTILA
}

Kulcsszavak:

világgazdasági verseny globalizáció transzatlanti együttmüködés és versengés nemzetközi versenyképesség gazdasági szuperhatalmak

Az alábbi cikk a nagy regionális gazdasági blokkok (EU, USA, Japán) globális versenyének és kooperációjának mozgatórugóit és aktuális fejleménveit értékeli. A reálgazdasági és kereskedelmi kérdéseken túl kitér a monetáris kapcsolatokra és a nagy régiók versenyképességének alakulasára is. Az elmúlt évtizedben a globalizáció nyomán a nagy régiók egymásra utaltsága nỗtt, és új hatalmak (elsősorban Kína) megerösödése indult meg. Európa folyamatosan veszít nemzetközi versenyképességébốl és növekedési potenciáljából, jóllehet számos területen rendelkezik kedvezö adottságokkal.

Az elmúlt század utolsó évtizede alapvetően a világpiac dinamikus bỏvülésének és az egyre gyorsuló transznacionalizálódásnak a jegyében telt el. Egy ilyen idöszakban csak az az ország vagy régió lehetett és lehet sikeres, amely képes betagozódni a nemzetközi áramlatokba. Ez persze egy sor hagyományos fogalmat - mint például a nemzeti szuverenitás - átértékel, és számos új dilemmát és megoldandó kérdést vet fel. Korunkban választ kell adni azokra az alapvetỏ kérdésekre, amelyek már gyakran túlmutatnak a közgazdaság-tudomány keretein, mint például a nemzetközi gazdasági és pénzügyi intézményrendszer reformja, a globalizáció és a technológiai forradalom pozitív hatásainak szétterítése az egész világon, a negatív hatások kordában tartása, és hasonlók. Azzal mindenki egyetért, hogy ha nem is látszanak a gazdasági világrend jövőjének kristálytiszta körvonalai, az bizonyos, hogy a nemzetközi gazdaság régen volt ilyen gyorsan változó „kedvében”.

A világgazdaság töretlen fejlödése iránt 2000 nyarán még osztatlan volt a bizalom. A világ gazdasági vezetői úgy érezték, hogy minden okuk megvan a gazdasági helyzet feletti elégedettségre. Az Egyesült Államok számára a túlfütött gazdaság lehütése és a „puha földet érés” levezénylése adott feladatot, ami akkor még nem tünt különösebben nehéznek. Biztatóak voltak a munkaerö-piaci, fogyasztási és ipari termelési adatok is. Európában is folyamatosan duzzadt a vállalatok rendelésállománya, a fogyasztói bizalom nagyobb volt, mint a korábbi ciklusok csúcsain, és a növekedés öröknek tủnt. Az eufória arra sarkallta az EU döntéshozóit, hogy elhatározták: Európának kell a világ legversenyképesebb, tudásalapú hi-tech gazdaságává válnia 2010-re. Japánban a vállalatok bizakodási indexe szintén hároméves csúcson volt, és a növekedésorientált gazdaságpolitika mikéntjéröl gondolkozott mindenki.

Az üzleti élet, a média és a kormányzati szféra nyilatkozatai tele voltak a gazdasági paradigmaváltás, az ,új gazdaság” sikereivel, és a megújult gazdaság növekedési potenciálja valóban szinte korlátlannak tủnt. Sem elméleti, sem gyakorlati ołdal- 
ról nem kérdöjelezte meg senki komolyan ezt a lelkesedést (pl. még Soros György is teljes bizalommal szállt be a Nasdaqba, jóllehet annak akkori árfolyama már régen elszakadt a reálfolyamatok által indokolható szinttól).

Azután egy év alatt kevesebb, mint a felére zsugorodott a világgazdasági fejlödés motorjának tartott technológia részvényeinek értéke. A szektor jelentősen eladósodott, ugyanakkor hatalmasak voltak a fejlesztési igényei, és bizonytalanok a közvetlen kilátásai. A korábbi eufóriát a kijózanodás és az átstrukturálódás követte. A Nasdaqon forgalmazott részvények összértéke egy év alatt 6700 milliárd dollárról 3000 milliárd dollárra esett, és azóta is tart folyamatos erodálódása, vagy stagnálása. Az értékvesztés az Egyesült Államok éves bruttó hazai termékének több mint harmadát tette ki.

A Világgazdasági Fórum 2002. február 4-én befejeződött New York-i értekezletén a világgazdaság közeljövőjének kérdöjelei, illetve a globalizáció világgazdaságra gyakorolt hatásának kérdései álltak a középpontban. A megújuló viták alaphangját Bill Gates, a Microsoft feje adta meg, aki elmondta, hogy semmiféle olyan jelet nem lát, ami a közeli fellendülésre utalna. A manapság sokat emlegetett globalizáció kérdésében - véleményem szerint - Kofi Annan ENSZ-fötitkárnak a Financial Times-ban megjelent cikke jelentette az alapvetést. Annan szerint téves nézet az, hogy a legnehezebb helyzetben lévök a globalizáció áldozatai volnának. Éppen az szerinte a probléma, hogy a globalizáció igen hiányosan halad előre, és vannak olyan térségek, amelyeket el sem ért. A tapasztalatok szerint éppen azok az országok küzdenek a legnagyobb gondokkal, amelyek egyelóre kimaradtak a globalizációból. Annan szerint emiatt nem tehetök felelössé a fejlett országok kormányai. Ö az üzleti világ felelösségét vetette fel, amely sokszor passzív a reménytelennek látszó térségekben, holott a legnagyobb és leghatékonyabb eszközkészlettel rendelkezik, hogy ösztönözze a fejlődést a világ bármely pontján. Az Európai Unióban mindeközben egyre nyíltabban ismerték be, hogy egy idöre kizárt a gazdasági növekedés, sőt a visszaesés sem elképzelhetetlen. Korábban úgy vélték, hogy Európa átvészeli az amerikai lassulást, majd annak elmúltával gyorsan évi két-három százalékos növekedési ütemet vesz fel. A becsléseket azonban fokozatosan lejjebb adták, és a pénzügyminiszterek időről időre kamatcsökkentésre ösztökélték a frankfurti jegybankot, amely azonban alapvetően vonakodik, mert ellenzi a ,mesterséges" élénkítést. Noha a két nagy uniós gazdaság - a francia és a német - elérte, hogy kereslet- és beruházás-élénkítési célból túlléphesse a költségvetési hiány uniós plafonját, beismerték: nincs nagy mozgásterük a növekedés beindításához. Az évek óta halogatott szerkezeti reform, a közös pénzügyi piacok évtizede csúszó reformja és a még mindig nagyon merev munkaerö-szabályozás modernizációja nem sikerült a gyarapodás idején, és most recesszióban kellene vállalni ezeket a súlyos politikai terheket. Közben Skandinávia és Hollandia alapvetően jól húzó gazdasága is megtorpant, és a fejlett világra vonatkozó elörejelzéseket rendre lefelé kellett módosítani az elmúlt évek során. A válságot és a bizonytalanságot tovább növelte a vállalati pénzügyi kimutatásokba vetett bizalom sosem látott megingása, ahogy egyre-másra kerültek napvilágra a cégek és az auditorok botrányos ügyei. 
Mindezek a rendkívüli gyorsasággal lejátszódó piaci fejlemények, valamint az ezzel egy időben, a mélyebb rétegekben lejátszódó események, mint például a világgazdasági keret-intézményrendszer reformjára irányuló törekvések, illetve annak hangos társadalmi elítélése (aminek leginkább Seattle-ben, vagy Genovában lehettünk szemtanúi), a transznacionalizálódás rohamos növekedése, az EU egyre kétségbeesettebb rohama az Egyesült Államok gazdasági hegemóniája ellen, a világtörténelem első jelentős monetáris uniójának és egy új világpénz bevezetésének ténye hihetetlenül izgalmassá teszik ezt a korszakot. Ez még akkor is igaz, ha a technológiai forradalmon alapuló globális gazdasági paradigmaváltás bekővetkezése egyelöre nem tekinthetö igazoltnak.

Ezek az idők természetesen hatalmas feladatok elé állítják a gazdaság pénzügyi közvetítő rendszerét is. A bankok, befektetési bankok és egyéb nagy intézményi befektető cégek, csakúgy, mint a világ tözsdéi, szédületes változásokat élnek meg. Az Európában tevékenykedő intézmények számára a feladvány még bonyolultabbá vált azáltal, hogy a globális átrendezödési hatások mellett a monetáris unió bevezetésével járó kihívásoknak is meg kellett és kell felelniük.

A Eurochambres 2005 márciusában nyilvánosságra hozott tanulmánya szerint az Európai Unió az Egyesült Államok hetvenes évekbeli versenyképességi szintjén áll. Amerikában 1978-ban volt jellemzỏ a 64\%-os foglalkoztatottsági arány, és 1979-ben költöttek annyit K+F-re, mint Európában 2004-ben. A tanulmány szerint az EU csak 2056-ra érné el az amerikai termelékenységi rátát, de kizárólag akkor, ha a termelékenység európai növekedése évi fél százalékkal meghaladná a tengeren túlit.

Amikor Bill Clinton 1992-ben megkezdte elnöki munkáját, bejelentette, hogy Németországtól fog tanulni. Eltekintve az azóta kialakult politikai viszonyoktól, ma már bizony gazdasági értelemben is furcsállnánk egy ilyen kijelentést. Ha összehasonlítjuk az angolszász országok és a nagy eurózóna tagállamok, illetve Japán gazdasági teljesítményét, azt tapasztaljuk, hogy drámai átrendeződés következett be az elmúlt másfél évtizedben. 1990 óta az angolszász országok (USA, Ausztrália, Anglia, Kanada) GDP növekedése számottevően meghaladta a francia, német, olasz, illetve japán ütemet. Az első csoportban az átlagos növekedés 30\%-os, a másikban ennek alig több mint a fele volt! (Ha Írországot is belevesszük az első csoportba, a különbség még szembetűnöbb). Az egy före jutó GDP Németországban még az egyesülés után is 3 százalékponttal nagyobb volt, mint Angliában (1991-ben), de 2004-re már 11 százalékponttal alacsonyabb volt! Olaszország pedig 2\%-os kezdeti előnyét 9\%-os hátrányra változtatta. El kell ismerni azonban, hogy a skandináv országok és Hollandia az európai nagyokhoz képest kimondottan jól teljesítettek. Ha megvizsgáljuk a második világháború óta eltelt idöszakot, egy érdekes „,hullámvasutat" látunk: 1950-ben a három nagy európai ország és Japán az USA fejlettségének mindössze 35\%-án állt, amit 1991-re 80\%-ra tornáztak fel, de 2004-re visszazuhantak az 1973-as szintre (70\%-ra). Mintha az elmúlt húsz évben egy helyben jártak volna. Ennek a relatív visszafejlödésnek több oka is lehet, melyek közül a termelékenységbeli különbség az egyik legfontosabb. A másik bünös a munkaeröpiac európai rugalmatlansága. Az ötvenes és hatvanas években az amerikai munkanélkü- 
Marján Attila : Globális verseny a világ jelentős gazdasági blokkjai között.

Tér és Társadalom 19. évf. 2005/1. 21-42. p.

liség sokkal magasabb volt, mint az európai, ma éppen fordított a helyzet. Alapvetỏen nem az amerikai szint csökkent, hanem az európai kezdett szárnyalásba: az amerikai munkanélküliség nagyjából a negyven évvel ezelőtti szinten állt 2004-ben, míg Németországban, Franciaországban és Olaszországban 8-10\% volt. A befektetések megtérülése is különböző a két országcsoportban: az angolszász világban kétszer nagyobb volt, mint a kontinentális Európában! És itt sem arról lenne szó, hogy az an golszászok javultak, hanem arról, hogy Európa és Japán eredményei romlottak (Japán esetében drámaian: a befektetések megtérülését [fordított értékben] mérö Icor mutató a harminc évvel ezelötti 3-ról, 2004-re 20-ra nőtt.) A kontinentális nagy gazdaságok relatív visszaesését az is magyarázza, hogy a második világháborút követỏ évtizedekben rendkívül nagy (az USA-hoz mért) termelékenységi lemaradást kellett (és tudtak) behozni (Wolf 2005). Ez egy egyszeri, történelmi kihívás és lehetöség volt. De a probléma igazából az volt, hogy nem voltak képesek az első nagy lendületủ hullám után meghozni a strukturális átalakítási döntéseket, amelyek a globális kihívásoknak való megfelelés miatt lettek volna szükségesek. A hatvanas-hetvenes években - a jólét idején - az újraelosztásra, magas adózásra, jóléti intézményekre alapuló modell erösödött meg. Ez a modell azonban gúzsba kötötte a flexibilitást, az újitó energiákat, és a gazdasági szereplök alkalmazkodó-képességét. Mindez a termelékenység csökkenéséhez és - a modell céljaival ellentétesen - növekvö munkanélküliséghez vezetett. Egy másik fontos jelenség is megjelent: a kontinentális társadalmak egyre gazdagabbá váltak, de a rendelkezésre álló munkaerö egyre fogyatkozott, jelentösen csökkentve a belföldi keresletet, vagyis kialakult egy krónikusan magas megtakarítási szint, egy krónikusan alacsony hazai kereslettel párosulva. További, történeti alapú negatív tényezőnek bizonyult az is, hogy mind a kontinentális európai országok (föképp Németország), mind Japán tradicionálisan fejlett ipari háttérrel, kultúrával rendelkeztek. Amikor tehát a szolgáltatási szektor forradalma beindult, egy hatalmas erejü és beágyazottságú ipari bázist kellett „mozgatniuk”. A nyolcvanas évekre pedig kiderült, hogy a világverő iparvállalatokra épülö gazdasági stratégia korszakának vége, már csak azért is, mert a globalizáció előnyeit kihasználva ezek a cégek egyre inkább az olcsóbb munkaeröt kínáló régiókban telepednek le. A szolgáltatási szektor pedig ezekben az országokban nehezebben tudott fejlödni a belgazdasági tradíciók és szabályok miatt (lásd késön jövő̉k elönye). Ennek a jelenségnek egy speciális, de rendkívül fontos aspektusa az információtechnológia alkalmazása. Ez egy rendkívül robbanékony, változékony ,iparág”, amely a legutóbbi idókben az egész gazdaság fejlődésében kulcsszerepet játszott, de egyben egy olyan szektor is, amely rendkívül nagy rugalmasságot igényel. A rugalmasságot az egész gazdasági környezetére kell érteni, melybe beletartoznak a gazdasági keretszabályok, intézmények és a munkaerö-szabályozás flexibilitása is. A csőd, vagy az elbocsátások drágasága komoly visszatartó erő ennek a hiper-reaktív és mozgékony üzletnek a számára. A monetáris politika, illetve az EU gazdaságpolitikai szabályainak rugalmatlansága szintén gyakran felmerült, mint az eurózóna problémáinak okozója, csakúgy, mint a túlzott export-függőség (illetve az elégtelen hazai kereslet). Érdekes módon a relatíve gyenge belsó kereslet 
ellenére az euró inflációja tartósan $2 \%$ felett maradt, ami a piaci erők elégtelen müködésére is utal. Az angolszász országok gyorsabban tudták gazdaságaikat szolgáltatás-orientálttá tenni (főleg ami az IT szektort illeti), és pénzügyi rendszerük is hatékonyabbnak bizonyult a megtakarításoknak a fogyasztás, illetve beruházások irányába csatornázásában. Természetesen semmi sem tart örökké, a világ rendje a változás, és a szerencse forgandó. Az USA számára például, dacára meggyőző gazdasági tevékenységének, komoly fenyegetés a hatalmas méretủ ikerdeficitje, és az angol gazdaság fejlödésében is mutatkoznak a lassulásra irányuló jelek.

Mindezzel együtt Európa több szektorban is versenyképes, sőt egyesekben világelső is. Az öreg kontinens erós a félvezetö-gyártásban, mobiltechnológiában, az orvosi müszergyărtásban és a környezetvédelmi technológiák területén, igaz relatíve gyenge az IT iparban és a biotechnológiai szegmensben. Az egyre fontosabbá váló nanotechnológiai szegmensben Európa megelőzi Amerikát a tudományos kutatás területén, de elmarad a kutatási eredmények gyakorlati kiaknázásában. Ez nem utolsósorban annak „köszönhető”, hogy egy szabadalom levédetése négyszer anynyiba kerül Európában, mint a tengerentúlon. Ráadásul néhány ún. lisszaboni cél ellent is mond egymásnak: például a foglalkoztatás növelése (föleg az alacsony képesítésủ kategóriában) rövid távon óhatatlanul csökkenti a termelékenységet. (Megjegyezzük azonban, hogy nem mindenki fogadja el a nemzetközi termelékenységi összehasonlítások eredményeit: egy 2005-ös Deutsche Bank tanulmány szerint az 1990 óta mért európai termelékenységi elmaradás alapvetỏen a különbözỏ besorolási, mérési és számítási módszerek okozta statisztikai torzulás.) Tény mindenesetre, hogy az USA évente 100 milliárd euróval többet költ kutatás-fejlesztésre, és az egy före eső bejegyzett szabadalmak száma is a négyszerese az európainak. Ráadásul, amikor cselekvésre kerülne a sor, az európai vezetök keze meg-meginog (gondoljunk csak arra, hogy az európai GDP 70\%-át adó szolgáltatási szektor egységes piacát megalapozó irányelvet egyes piacukat féltő tagállamok nyomására alaposan felhigították). Mindezzel együtt vannak pozitív fejlemények is: Spanyolországban például két hónapról két napra csökkent az az idő, amely egy vállalat felállításhoz szükséges. Franciaország állja a 35 órás munkahétröl szóló törvény visszavonása miatti szakszervezeti tiltakozásokat. Ahol pedig a kormányok nem lépnek elég gyorsan, ott a vállalatok veszik kezükbe az irányítást: Németországban a cégek drasztikus leépitéseket eszközölnek. Az európai vállalati szektornak szüksége is van az erösödésre, hiszen jól lehet, vannak globális mércével is jelentősnek számító cégek, koránt sincsenek elegen. A 2004-es FT Global Survey adatai szerint az 500 legnagyobb cégből 247 volt amerikai és csak 156 európai (és 92 ázsiai). Ráadásul az első 20 között 15 amerikai volt. Egyes vélemények szerint az USA-ban tapasztalható erősebb növekedés ( 3 illetve $2 \%$ az elmúlt 15 év átlagában) alapvetően annak köszönhetö, hogy az amerikai népesség gyorsabban nő, mint az európai: Amerikában átlagban 1,2\%-os, míg az öreg kontinensen csak $0,4 \%$-os volt a népesség növekedése.

Fontos látni azt, hogy míg Európa az USA-hoz méri magát, és ahhoz próbál felzárkózni, Amerika nem sokat törődik ezzel, hanem rohan elöre egyre gyorsabb iramban, nehogy az új globális ellenfelek, elsősorban Kína versenyhátrányba hozza. 
Európának tehát nemcsak egy jelentös mértékủ hátrányt kellene ledolgoznia, hanem mindezt egy egyre gyorsabban futó igazodási pont ellenében kell megtennie!

Az Amerika és Európa között fennálló különbség az egy före esö GDP tekintetében alapvetően három faktor eredménye: harmadrészben az alacsonyabb munkatermelékenységnek, harmadrészben a kevesebb ledolgozott munkaórának, harmadrészben pedig az alacsonyabb foglalkoztatási rátának. A kilencvenes évektöl kezdödô termelékenységi lemaradásnak a beruházások és a verseny alacsony szintje, illetve az innovatív termelési megoldások elégtelen szintủ alkalmazása voltak a mögöttes okai. Az európai termelékenység azonban nem drámaian kisebb, mint az amerikai: az EU-15 az amerikai szint 92\%-án, az EU-25 pedig a 83\%-án áltt 2004-ben. Számos tagállamban (Luxemburg, Franciaország, Belgium, Írország, Hollandia) még magasabb is a termelékenység, mint az USA-ban. Fontos tudni azonban, hogy ott, ahol magasabb a munkanélküliség, magasabb a kimutatott termelékenység is! Az igazi probléma azonban valójában az információ-technológiai szektor, és az emberi tőkébe való befektetések relatív lemaradásában van. Érdekes módon az európai IT iparág termelékenysége majdnem eléri az amerikai szintet, de a mérete mindössze a fele annak! Ennek megfelelöen súlya az összes termelékenységi növekedésben is kisebb (40\%, összevetve az amerikai $60 \%$-kal). Mindez párosul azzal, hogy Európában a $\mathrm{K}+\mathrm{F}$ befektetések sokkal kisebbek: csak a GDP 1,9\%-ára rúgnak a 15 régi tagállamban, szemben az amerikai 2,6\%-kal. Ebben a legnagyobb ludas a magánszektor, és jóval kevésbé a tagállamok maguk. További hátrány, hogy az USA népességének egyharmada rendelkezik valamilyen felsöoktatási képzéssel, míg ez az európaiaknak csak az ötödére igaz, és az egyetemi kutatások rendszere is fejlettebbnek tekinthetö Amerikában. Ráadásul az USA a világ legnagyobb agyelszívója (igaz ez a szeptember Il-i események után már nem olyan mértékü, mint annak elötte).

További fontos szempont, hogy Európában a munkaórák száma folyamatosan csökkent a hetvenes évektől kezdve, míg Amerikában konstans maradt, ráadásul ott a munkaerőpiac és a lakáshitelezési piac is sokkal rugalmasabb.

Közhelynek számít az is, hogy a cégeket végül is emberek alapítják és irányítják, tehát az általános vállalkozói szellem elengedhetetlen feltétele a fejlödésnek. Kétségtelen, hogy ebben Amerika messze elöttünk jár.

Az OECD 2005 márciusában ismertette jelentését, amely értékelést adott arról, hogy az amerikai gazdasággal összehasonlítva miért is esett vissza a növekedési lendület Európában és Japánban, az utóbbi évtizedben. Franciaországban, Németországban és Olaszországban az egy före jutó GDP 30\%-kal alacsonyabb, mint Amerikában, és ez a különbség egyre nö. A jelentés egyik érdekes megállapítása, hogy az országok tanulhatnak egymástól, de el kell kerülniük a másik szolgai követését.

A dokumentum legfontosabb javaslatai a következők.

- javítani kell a munkaerö kihasználását, föként az 55 éven felüliek esetében, a munka folytatására való ösztönzéssel;

- enyhíteni kell az üzleti életet sújtó terheket, adminisztratív elörrásokat (föként a szolgáltatási szektorban);

- teljesen liberalizálni kell a postai és a vasúti szektort; 
Marján Attila : Globális verseny a világ jelentös gazdasági blokkjai között.

Tér és Társadalom 19. évf. 2005/1. 21-42. p.

- javítani kell az EU közbeszerzési rendszerét;

- fokozni kell a versenyt a hálózati iparban, ahol a piac régebbi szereplői még mindig monopolisztikus előnyöket élveznek;

- csökkenteni kell az agrártermelök támogatását, és javítani kell a nem-EU országok agrárpiacokhoz való hozzáférését;

- javítani kell az Európán belüli munkaerő-mobilitást a nyugdíjjal összefüggö jogok hordozhatóságának megkönnyítésével;

- alkalmazni kell a pénzügyi szolgáltatásokról szóló akcióterv minden jogszabályát;

- ellen kell állni a nemzeti bajnokok támogatására tett kísérleteknek.

A jelentés megpróbál szembemenni azzal a vélekedéssel, hogy az európaiak elönyben részesítik a több szabadidöt a magasabb bérekkel szemben, s ezért vonulnak korábban nyugdíjba. Az OECD szerint a korai nyugdíjbavonulás valódi oka nem kulturális, hanem fiskális jellegú: a tagországok szabályai nem ösztỏnzik az embereket a munkában maradásra.

A különbségek oka tehát kézenfekvőnek tünik: az európaiak azért szegényebbek az amerikaiaknál, mert kevesebbet dolgoznak, a japánok pedig azért, mert kevésbé hatékonyan dolgoznak. Az OECD szerint a foglalkoztatásban meglévő különbséget 60\%-ban magyarázzák az EU-tagállamok szabályozásában tetten érhetó anomáliák. A 25-55 év közötti korosztályban a foglalkoztatási szint megegyezik az EU-ban és az USA-ban, a baj a fiatalok és az idősek korcsoportjában van! Németország gazdasági helyzete különösen aggasztó, és nem kedveznek neki a globális folyamatok sem (magas olajárak, erős euró). Japán lemaradását a piaci verseny és a dereguláció hiánya, illetve az állami agrárdotációk magas szintje okozza. Ehhez társul még a gyenge makrogazdasági politika és a pénzügyi rendszer súlyos válsága is. A japán kormány eközben a vállalati szektort hibáztatja, amiért az nem kanalizálja a lakosság irányába (fizetés, illetve munkahelyteremtés formájában) egyre növekvő profitját. Mindkét régió előtt sok feladat áll még a munkaerỏpiac liberalizálása területén, ami azonban fájdalmas politikai döntéseket (minimálbér-csökkentés, munkaóranövelés, szociális jogok megkurtítása stb.) jelent.

Az EU szemszögéböl tehát az a legfontosabb dolog, hogy vélt vagy valós versenyhátrányát a nemzetközi versenytársaival szemben hogyan tudná ledolgozni, esetleg elönnyé fejleszteni. Ebben természetesen van egy hatalmas hátráltatója: a saját szétaprózottsága. Ha az európai integráció történetét a nemzetközi verseny aspektusából nézzük (és meggyőzödésem, hogy ez a legfontosabb aspektus), akkor világos, hogy annak legfontosabb motivációja a piac méretének és egységességének növelése volt, ledolgozandó a hátrányt a másik két nagy nemzetközi gazdasági eröközponttal szemben. Ennek egyik legfontosabb mérföldköve az egységes piac bevezetése 1993-ban, de egyértelmü, hogy eddigi legnagyobb szabású eseménye a közös európai valuta létrehozása volt. 
Marján Attila : Globális verseny a világ jelentős gazdasági blokkjai között.

Tér és Társadalom 19. évf. 2005/1. 21-42. p.

A nemzetközi vezető pozícióért folytatott küzdelemben szintén mérföldkőnek számít az Európai Unió 2000. évi lisszaboni és 2002. márciusi, barcelonai csúcsértekezlete is. A csúcsok legfontosabb üzenete az volt, hogy 2010-re Európa hatékonyságban és innovációban utol kell, hogy érje Amerikát, de közben meg kell, hogy tartsa szociális rendszerét. Szabályozott, szociális és környezetbarát liberalizálás - nagyjából így lehetett összegezni az Európai Unió fejlesztési célját az évtized végéig. Sor került számos szektor, köztük az áram- és gázpiac megnyitására, de a munkaeröpiacot nem liberalizálták megfelelően.

A lisszaboni stratégia azonban egyrészt a kedvezőtlen gazdasági folyamatok, másrészt a stratégia alapvetö hiányosságai és szétfolyó jellege miatt 2005-re, a félidei értékelés idejére kiábrándító eredményeket produkált. Az Európai Bizottság ezért, válaszul a stratégiát ért kritikákra (többek között a már említett Kok-jelentésre) 2005 februárjában új, nagyszabású növekedési és munkahely-teremtési stratégiát fogadott el. A remények szerint a tervezett intézkedések 2010-ig jelentős mértékben növelik majd az európai GDP-t, és több mint 6 millió új munkahelyet teremtenek. Ez persze jóval kevesebb annál a 22 milliónál, ami a 2000-es lisszaboni programban megcélzott $70 \%$-os általános foglalkoztatási szint eléréséhez szükséges. A megújított stratégia - amelyben már nem szerepel az a célkitúzés, hogy az EU 2010-re a világ legversenyképesebb és legdinamikusabb gazdasága legyen - az eredetileg szétszórt és kívánságlista-szerủ célrendszer helyett két gazdasági prioritásra, a növekedésre és a munkahelyteremtésre összpontosít. A bizottsági program szerint a gazdaság modernizálása lesz az euró és a bővítés után Európa következő nagy projektje, részben feladva a szociális és környezetvédelmi dimenziót. Az eröteljesebb növekedést és az új munkahelyek teremtését az alábbi három módon kellene elérni a Bizottsági reform-javaslat szerint:

- Európának vonzóbbá kell válnia a befektetések és a munka világa számára;

- A tudásnak és az innovációnak kell az európai növekedés motorjának lennie;

- Az EU-nak úgy kell alakítania politikáit, hogy a vállalkozások több és jobb munkahelyet tudjanak létrehozni.

A célok megvalósításában persze a tagállamok játsszák a legfontosabb szerepet, ezért kritikus kérdés, hogy ök mennyire lesznek majd képesek azonosulni a brüsszeli programmal, amely a szociális modell irányából elmozdult a versenyképesebb modell irányába.

Újra és újra felszínre kerülnek az EU-tagállamok közötti gazdaság- és társadalompolitikai ellentétek. Legutóbb, 2005 februárjában, az Európai Parlamentben folytatódott a csata a liberalizálást kívánók, illetve a szociális védőhálót erőteljesebben védelmezni próbálók tábora között. Európa kiutat keres tehát a pangásból, és azt reméli, hogy a liberalizálás felgyorsítja ezt a folyamatot: jelenleg úgy látszik, hogy a piaci hatékonyság hívei enyhe többségben vannak a szociális szempontokat hangsúlyozókkal szemben, igaz számos kritika érte az új stratégiát annak állítólagos „hiperliberalizmusa” miatt. 
Henry Kissinger gúnyos hangneme azonban egyelöre indokolt, amikor azt kérdezi, hogy mi is Európa közvetlen telefonszáma. Mindenesetre az európai országok egy hatalmas és eddig példa nélküli lépést tettek piacaik egységesítése felé az euró bevezetésével, és nem kell kiváló jósnak lenni ahhoz, hogy az ember elöre lássa ennek valószínü folytatódását az élet más területein, folyamatosan közelítve az egykori szabadkereskedelmi övezetet egy politikai unió felé.

Az Egyesült Államok és az EU a világkereskedelem két legnagyobb szereplője, együttes súlyuk a nemzetközi kereskedelemben több mint 50\%. Ezen belül az EU részesedése mind az export, mind az import tekintetében az USA-énak mintegy háromszorosa, látszik tehát, hogy az EU az Egyesült Államoknál sokkal inkább exportorientált és nyitott gazdasági térség.

Japán pedig hagyományosan zárt, és az utóbbi években jelentős strukturális problémákkal küszködỏ gazdaság, amely megpróbál kitörni elszigeteltségéből, és saját regionális befolyásának növelését célozza meg. Ennek egyik fontos fejleménye az 1999-ben megrendezett ASEAN csúcs, amely Japán mellett kínai és dél-koreai részvétellel zajlott. A résztvevők egy új közös piaci fejlödés előtt nyitották meg az utat. A manilai csúcsértekezleten megállapították, hogy az eddig megvalósított gazdasági integráció lehetővé teszi vámunió, közös piac és közös pénz bevezetését. Az illetékes minisztereket megbízták a vonatkozó tervezetek kidolgozásával. Ennek lényege, hogy szorosabb gazdasági, kereskedelmi, pénzpiaci együttmüködést helyeztek kilátásba, amely kiterjed majd monetáris kérdésekre is. Így kívánják megerősíteni pénzügyi és bankrendszereiket, elejét venni a két évvel azelöttihez hasonló válságnak. A kezdeményezés azonban eleddig nem hozott semmilyen számottevő áttörést.

A japán gazdaság maga is súlyos válsággal küszködik. Mivel a japán gazdaság a második legerősebb a világon, ráadásul viszonylag zárt, autonómiája ennek megfelelöen számottevő. Vagyis: hiába pozitívak esetenként (újabban egyre ritkábban) a New York-i jelzések, ha a belföldi hatások ennek ellentmondanak. Általános vélemény szerint Japánban a bankszektor a valóban kritikus pont: a behajthatatlan hitelek - összegük 400 milliárd dollár felett van - meghaladják a türéshatárt. Ezért határozta el a jegybank, hogy a rossz adósságok terhe alatt roskadozó szektor helyzetêt bankrészvények vásárlásával enyhíti. Az emiatt kialakult nézeteltérés az amerikai kormány és a japán kabinet között abban foglalható össze, hogy az elöbbi ezt helyes irányban tett, ám korántsem elégséges lépésnek minősítette, az utóbbi erre kívánta korlátozni a beavatkozást. A japánok szerint, ha - akár közpénzekből - nem segítik ki a pénzintézeteket, akkor megbénulhat a hitelnyújtás gépezete, és elsősorban a komolyabb kockázatoknak kitett kis- és középvállalatok maradnak pénzeszközök nélkül. Az ezzel szemben álló argumentum: amikor az egész gazdaságra ránehezedik az adósságok és a defláció terhe, amikor a beruházások radikális csökkentését tervezik, akkor átfogó lépésekre volna szükség, éppen a belföldi vásárlási kedv élénkítésére. A tokiói kormány azonban félt a radikális lépésektől, így a vállalkozások, a bizonytalanság miatt, tartózkodtak új költségek vállalásától, beruházásoktól, és elhúzódott a defláció. Ezzel is összefügghet a japán jegybank 2002-es felmérésének eredménye: a cégek továbbra sem bíznak a jövőben. A tokiói tőzsde 2002 októberében 19 (!) évvel azelötti mélypontra zuhant. 
Marján Attila : Globális verseny a világ jelentős gazdasági blokkjai között.

Tér és Társadalom 19. évf. 2005/1. 21-42. p.

\section{TÁBLÁZAT}

Az euróövezet, az EU, az USA és Japán legfontosabb gazdasági adatai 2003-ban (The Most Important Economic Data of the Eurozone, the USA and Japan in 2003)

\begin{tabular}{|c|c|c|c|c|c|}
\hline Népesség, GDP és munkaerö & Egység & Euróövezet & $E U$ & USA & Japán \\
\hline 1. Össznépesség & millió & 308,7 & 456,7 & 291,1 & 127,6 \\
\hline 2. Munkaerỏ részvételi aránya & $\%$ & 68,6 & 69,3 & 75,8 & 78,2 \\
\hline $\begin{array}{l}\text { 3. Elöregedési arány } \\
\text { (age dependency) }\end{array}$ & $\%$ & 49,4 & 46,7 & 50,3 & 49,0 \\
\hline \multicolumn{6}{|l|}{$G D P$} \\
\hline $\begin{array}{l}\text { 4. Bruttó hazai termék (GDP) } \\
\text { (Vásárlóerỏ paritáson) }\end{array}$ & billió EUR & 7,3 & 10,1 & 9,9 & 3,2 \\
\hline $\begin{array}{l}\text { 5. Bruttó hazai termék, } 1 \text { före } \\
\text { eső (Vásárlóerő paritáson) }\end{array}$ & ezer EUR & 23,5 & 22,1 & 34,1 & 25,1 \\
\hline $\begin{array}{l}\text { 6. Munkaerő termelékenység } \\
\text { (Vásárlóerô paritáson) }\end{array}$ & $\begin{array}{l}\text { euróövezet= } \\
\qquad 100\end{array}$ & 100,0 & 92,3 & 119,7 & 88,7 \\
\hline $\begin{array}{l}\text { 7. Munka bevétel arány (fog- } \\
\text { lalkoztatotti kompenzáció/GNP) }\end{array}$ & $\%$ & 69,1 & - & 70,0 & - \\
\hline \multicolumn{6}{|l|}{ Hozzáadott érték szektoronként } \\
\hline $\begin{array}{l}\text { 8. Mezögazdaság, halászat, erdé- } \\
\text { szet } \\
\text { 9. Ipar (beleértve az építöipart) }\end{array}$ & az egész \%-a & $\begin{array}{r}2,3 \\
26,9 \\
70,9\end{array}$ & 2,1 & $\begin{array}{l}0,8 \\
19,7 \\
70,5\end{array}$ & $\begin{array}{l}1,3 \\
29,1 \\
606\end{array}$ \\
\hline $\begin{array}{l}\text { 10. Szolgáltatások } \\
\text { Megtakarítás és beruházás }\end{array}$ & $\begin{array}{l}\text { az egesz } \% \text {-a } \\
\text { az egész } \% \text {-a }\end{array}$ & & 71,1 & & 69,6 \\
\hline 11. Bruttó megtakarítás & & 20,3 & - & 13,5 & 25,7 \\
\hline 12. Bruttó tőkeképzés (GFCF) & GDP \%-a & 19,8 & 19,2 & 18,4 & 24,2 \\
\hline Háztartások & GDP \%-a & & & & \\
\hline \multicolumn{5}{|l|}{$\begin{array}{l}\text { 13. Elkölthetö bevétel (DI) / fö } \\
\text { (PPP) }\end{array}$} & 15,7 \\
\hline 14. Bruttó megtakarítás & ezer EUR & 14,3 & - & 3,7 & 13,0 \\
\hline 16. Tartott pénzügyi eszközök & DI $\%-a$ & 286,2 & - & 419,9 & 445,3 \\
\hline $\begin{array}{l}\text { 17. Adósságot megtestesítoo } \\
\text { értékpapír állomány (bruttó) }\end{array}$ & $\begin{array}{l}\text { DI \%-a } \\
\text { DI } \%-a\end{array}$ & 80,9 & - & 113,4 & 108,6 \\
\hline \multicolumn{6}{|l|}{ Nem pénzüigyi vállalatok } \\
\hline 18. Bruttó megtakarítás & GDP \%-a & 8,9 & - & 10,2 & 15,7 \\
\hline 19. Tartott pénzügyi eszközök & GDP \%-a & 131,8 & - & 113,6 & 139,9 \\
\hline $\begin{array}{l}\text { 20. Bruttó adósságállomány } \\
\text { Államháztartás }\end{array}$ & GDP \%-a & 78,9 & - & 67,5 & 110,5 \\
\hline 21. Kiadás & GDP $\%$-a & 49,1 & 48,5 & 32,4 & 39,2 \\
\hline 22. Többlet (+) vagy hiány (-) & GDP $\%-\mathrm{a}$ & $-2,7$ & $-2,8$ & $-4,6$ & $-7,9$ \\
\hline 23. Bruttó adósságállomány & GDP $\%-a$ & 70,7 & 63,2 & 47,7 & 141,3 \\
\hline \multicolumn{6}{|l|}{ Kïlgazdaság } \\
\hline $\begin{array}{l}\text { 24. Áruk, szolgáltatások exportja } \\
\text { 25. Áruk szolgálttatások importia }\end{array}$ & GDP \%-a & 18,8 & 12.4 & 93 & 122 \\
\hline 26. Folyó fizetési mérleg & GDP \%-a & 17,1 & 12,1 & 13,8 & 10,6 \\
\hline 27. Nettó közvetlen és portfólió- & GDP \%-a & 0,3 & 0,0 & $-4,8$ & 3,2 \\
\hline befektetés & GDP \%-a & 0,5 & 0,4 & 3,1 & $-2,8$ \\
\hline $\begin{array}{l}\text { 28. Pénzügyi eszközök- } \\
\text { kötelezettségek }\end{array}$ & GDP \%-a & $-10,5$ & $-11,1$ & $-24,1$ & 37,6 \\
\hline \multicolumn{6}{|l|}{ Monetáris és pénzügyi mutatók } \\
\hline 29. Hitel (piaci árfolyamon) & billió EUR & 10,4 & 13,4 & 7,7 & 5,9 \\
\hline $\begin{array}{l}\text { 30. Hitelviszonyt megtestesítö } \\
\text { értékpapírok állománya. }\end{array}$ & billió EUR & 8,7 & 11,6 & 16,4 & 6,5 \\
\hline 31. Tökepiaci kapitalizáció & billió EUR & 3,6 & 6,0 & 10,7 & 2,4 \\
\hline
\end{tabular}

Forrás: ECB statisztika, Frankfurt (2004). 
Mint már említettem, a világgazdasági kilátások Európa számára nem voltak túl kedvezőek az elmúlt években. A német üzleti bizalmi index például fokozatosan zuhant az elmúlt években. A Német Szövetségi Foglalkoztatási Ügynökség 2005 januárjában hozta nyilvánosságra sokkoló adatait, melyek szerint Németországban negatív rekordot döntött a munkanélküliség: 2005 elején az állástalanok száma meghaladta az ötmilliót. A szövetségi köztársaság fennállása óta soha nem volt ilyen magas az állástalanok száma, igaz a statisztikát rontotta az is, hogy egy korábbi reform keretében összevonták a munkanélküli és a szociális segélyben részesülők kimutatását. Tény azonban az, hogy egy jó darabig nem is várták a munkanélküliség csökkenését, és valóban, az februárban tovább romlott. A német gazdasági miniszter találóan így fogta meg a kialakult helyzetet: „A januári adatok ötmillió okot szolgáltatnak a munkaerö-piaci reformok folytatására". Az OECD 2005. elején szintén vészjósló elörejelzéseket tett közzé a német, a japán és az olasz gazdaság kilátásait illetően. Japánban tovább húzódhat a defláció, és az adósság mértéke (a GDP 160\%-a) is elviselhetetlenül magasnak számít. Németországban kismértékủ GDPcsökkenés is bekövetkezhet, és továbbra is igen gyenge marad a belsö kereslet.

Az elemzök azonban 2005-ben átlag feletti gazdasági bővülésre számítanak a világgazdaság egészének tekintetében. Az eurózóna tagállamai - mint láttuk -, ugyanakkor 2004-hez hasonlóan továbbra sem jönnek ki a lassú pangás állapotából. A GDP növekedési ütemére vonatkozó prognózisok enyhén csökkentek, melynek hátterében jelentős részben a magas olajárak állnak.

\section{1. ÁBRA}

Növekedés a fejlett világban

(Growth in the Developed Countries)

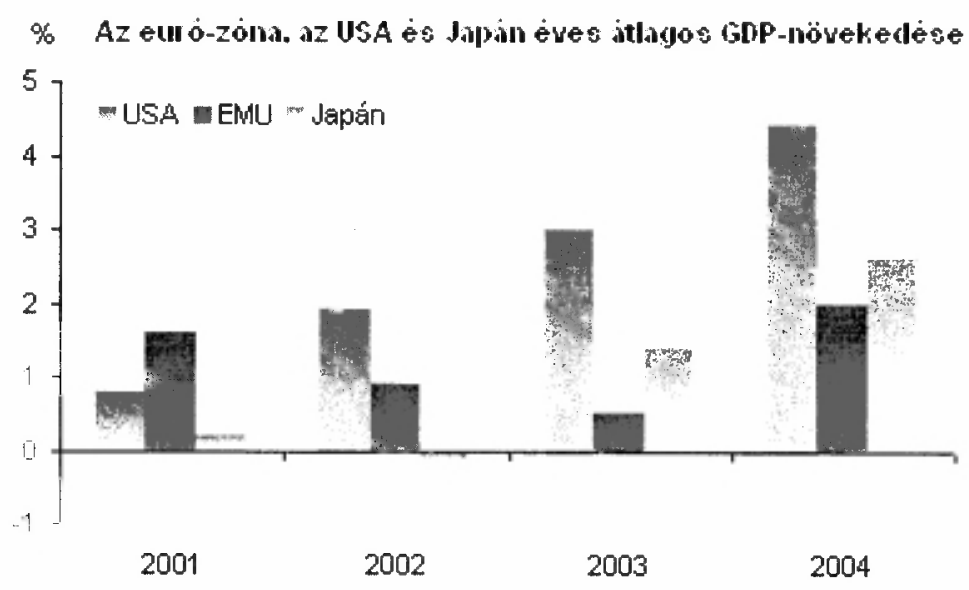

Forrás: Eurostat

Forrás: Eurostat. 
Marján Attila : Globális verseny a világ jelentös gazdasági blokkjai között.

Tér és Társadalom 19. évf. 2005/1. 21-42. p.

A világgazdaság szempontjából - bár egyre kisebb súllyal - elsősorban az amerikai gazdaság teljesítménye a meghatározó, amely viszont külső és belsö egyensúlytalanság állapotában van. Az USA külkereskedelmi mérlegének hiánya 2004 októberében 55,5 Mrd USD-re nött, ez közel 9\%-kal magasabb az egy hónappal korábbi adatnál. Az import bövülése meghaladta az exportét a gyenge dollárárfolyam ellenére is. A legnagyobb hiány továbbra is Kínával szemben áll fenn, 16,8 Mrd USD-t tett ki. Ha a folyó fizetési mérleg deficitjét dollárgyengítéssel próbálják mérsékelni, az az eurózóna termékeinek versenyképességét tovább rontaná.

Az Európai Bizottság öszi elörejelzése szerint 2005-ben az eurózóna és az EU egészének gazdasági növekedése valamelyest lassulni fog. A magas olajárak várhatóan az ázsiai országokat érintik a leginkább kedvezötlenül, ugyanakkor nem valószínű, hogy a kínai növekedés valamit is gyengülne.

Kína ugyan egyelöre nem nevezhetö pénzügyi nagyhatalomnak, de gazdaságának fejlödési üteme igen impresszív (2. ábra), és minden bizonnyal kulcsszerepet fog játszani a következő évtized gazdasági világrendjében. Sőt, egyes értékelések szerint (EUREN) a világgazdaság kilátásait már most a kínai növekedés lassulásának mértéke határozza meg elsősorban. Amennyiben a kínai növekedés 2005-ben nem érné el a 7\%-ot ${ }^{1}$, úgy a japán gazdaság ismét stagnálásba fordulhat, és az egész délkelet-ázsiai régió fejlődése megakad, ami az amerikai exportot is visszavetheti. Az Egyesült Államokban a kamatok lassú emelkedése mellett a laza költségvetési politika fennmaradására lehet számítani, ami meghosszabbítja a dollár gyengeségét.

\section{2. ÁBRA}

Gazdasági növekedés Kínában

(Economic Growth in China)

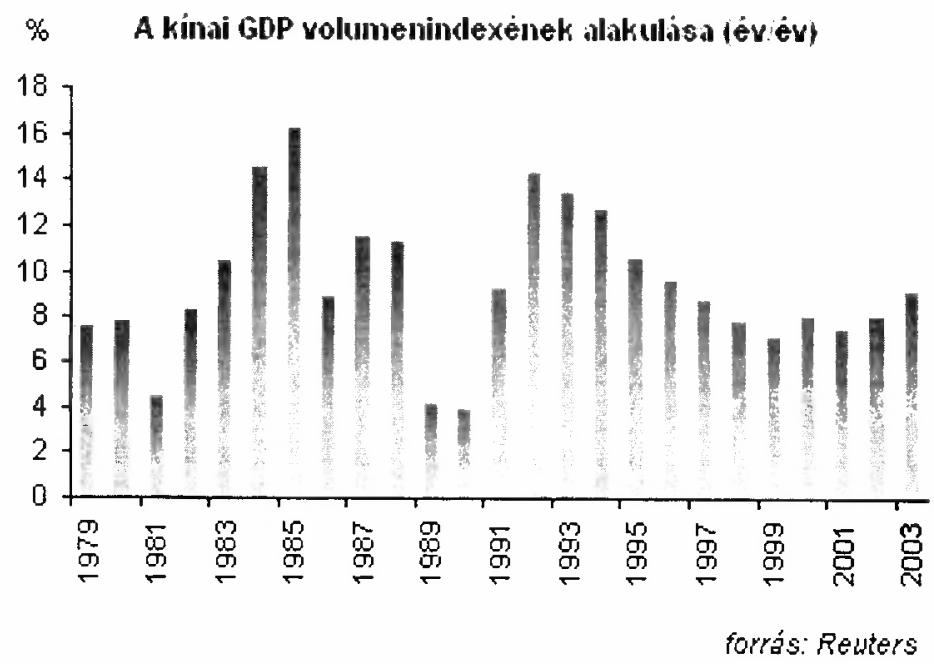

Forrás: Reuters. 
Két fontos, Kínához kapcsolódó lélektani határt is átlépett a globális gazdasági rendszer 2004-ben: Japán legfontosabb kereskedelmi partnere már nem az USA, hanem Kína volt! Egy 2005. eleji amerikai felmérés szerint pedig Kína megelőzte az Egyesült Államokat az alapvető mezögazdasági és ipari termékek fogyasztásában. A személyi számítógépek száma például 28 hónaponként megduplázódik a hatalmas országban. Jelenleg az ország gazdasága a hatodik legnagyobb a világon, ám dinamizmusa lélegzetelállító. Nyersolaj felhasználásban még az USA vezet Kína elött, gépkocsiból pedig az Egyesült Államokban 2004-ben még mintegy tízszer annyi futott, mint Kínában. Kína viszont már magasan vezetett a múlt év végén az USA elött televíziók, mobil telefonok, hütőgépek „,fogyasztásában". Ennél is fontosabb indikátora a kínai gazdaság elöretörésének, hogy a nagy kínai cégek elkezdtek „bevásárolni” az amerikai vállalati piacon. Egyre több indult el közülük a globális terjeszkedés útján. A Lenovo nevủ számítógépgyártó vállalat például 2005. elején 1,75 milliárd dollárért megvette az IBM PC részlegét, de akad példa felvásárlásokra a telekom és a gépgyártási szektorban is.

Ha ebben a kimondottan turbulens világgazdasági környezetben megnézzük a fontosabb szereplöket, azt kell mondanunk, hogy egyelöre a nemzetközi versengés két legfontosabb szereplöje mégiscsak az EU és az USA, föképpen igaz ez a pénzügyi szektorok vonatkozásában. A közöttük lévő viszony sajátos keveréke az együttmüködésnek és a retorziókkal megtüzdelt kemény versenynek.

Az USA-ban az egységes európai piac kiépítése és az egységes európai valuta megjelenése miatt komoly félelmek alakultak ki az „Európa-erödtól”. Ezek a félelmek idövel fokozatosan tompultak, s Washington az EU integrációját egyre inkább a lehetöségek Európájaként tekinti és kezeli.

Mindez persze nem jelenti azt, hogy ne lennének komoly nézeteltérések, olykorolykor kisebb kereskedelmi háborúk a két fél között: évekig tartott például az USA és az EU banánháborúja az új évezred elején. A nézeteltérések látszólagos elsimulása után az EU 2005 márciusában újra kiásta a csatabárdot, és bejelentette, hogy volt gyarmatainak kedvezve 2006-tól a latin-amerikai banán kvótát megszüntetné, és háromszorosára emelné a védővámot. A javaslat ellen a latin-amerikai országok vezetői azonnal tiltakoztak a Kereskedelmi Világszervezetnél. 2005. elején pedig a Boeing fenyegette meg Európát egy WTO vizsgálattal, ha nem áll el legfóbb vetélytársa, az Airbus állami támogatásától.

Ennél komolyabb ügynek tủnik a genetikailag módosított agrártermékek és a hormonkezelt marhák húsának ügye. Ezeket kitiltják az európai piacokról, miközben a WTO szerint az EU képtelen bizonyítani az egészségkárosító hatást. Ezért az USA 100\%-os büntetővámot vezetett be a francia sajtok ellen, amire válaszul a franciák bojkottálták a McDonald's éttermeket.

Komoly feszültségforrás az agrártámogatások kérdése is mindkét fél részéről. Washington - és a cairnsi csoportként ismert országtömörülés - folyamatosan követeli, hogy az EU számolja fel az export és a termelés támogatását. Az Európai Bizottság viszont azt sérelmezi, hogy kétmillió amerikai agrártermelöre 60 milliárd 
Marján Attila : Globális verseny a világ jelentős gazdasági blokkjai között.

Tér és Társadalom 19. évf. 2005/1. 21-42. p.

dolláros mezőgazdasági költségvetés jut, míg az EU-ban hétmillió érintettre mindössze 40 milliárdos.

Az alábbiak azonban kitủnően bizonyítják, hogy a két régió mennyire egymásra van utalva, és milyen csínján kell bánniuk - saját érdekükben - a kereskedelmi háború eszközeivel. Az EU-USA viszonyban 2001. második felének egyik legnagyobb hatású kereskedelempolitikai eseménye egy hatalmas kereskedelmi háború kilátásba helyezése volt. A felek végül is tartózkodtak ettöl, de az Európai Unió sokáig diplomáciai aduként használta az Egyesült Államokkal szemben hozott WTO-döntést, amely az amerikai exporttermékekre rekordnagyságú, 4 milliárd dollár értékủ kereskedelmi szankciók kivetésére jogosította volna fel az Uniót. Pascal Lamy, az Európai Unió kereskedelmi biztosa vezényletével az Unió ,higgadtan és megfontoltan" élt ezzel a komoly diplomáciai elönnyel. Brüsszel nem kívánt élni a szankciók fegyverével, ami mindkét fél számára valójában rendkívül káros kereskedelmi háborút indított volna el. Kemény tárgyalások kezdődtek azonban az Egyesült Államokkal az amerikai exportot tetemes adókedvezményekkel támogató törvények módosításáról. Az Egyesült Államok számos formában nyújt ugyanis adókedvezményeket az amerikai vállalatok exportból származó bevételeire. Az amerikai érvek szerint Washington csak az amerikai cégek ,,versenyhátrányát” igyekszik ellensúlyozni, mivel a legtöbb országban a cégeknek kizárólag a helyben termelt jövedelmük után kell adózniuk. A WTO döntése elutasította az amerikai érvelést, s az adókedvezményeket illegális exporttámogatásnak minősítette.

Az európai szankciók alkalmazása azonban nemcsak az amerikai vállalatokat sújtaná, hanem az európai fogyasztókat és az amerikai exporttól közvetlen függésben müködő vállalatokat is. Elemzök szerint ezért már egy kereskedelmi háború puszta lehetösége is megnehezítheti számos vállalat életét. A szankciók komoly fejfájást okozhatnak az olyan meghatározó amerikai exportöröknek is, mint a Boeing, a General Electric, vagy a médiaiparban a Walt Disney, valamint a Microsoft és a legnagyobb szoftvergyártók többsége.

Gondolatkísérlet gyanánt, ehelyütt szólnánk egy érdekes, 2002 júniusában közzétett kutatási eredményröl. ${ }^{2}$ A mannheimi Európai Gazdaságkutató Központ (ZEW) felmérése szerint az amerikai konjunktúra hatása a német és az európai gazdasági növekedésre a kilencvenes évek óta csökken. Ennek egyik oka a vállalatok multinacionális összefonódása, a globalizáció térnyerése lehet - mondják a kutatók, akik egészében véve óvatosságra intenek az új összefüggések megítélésében. A ZEWkutatócsoport az eddig szokásos elemzö módszereket (mindenekelött a kamatalakulás, a külkereskedelem hatásait) kiegészítette az egyre inkább impulzushordozó tőkepiacok, a multinacionális vállalatok és a vállalkozói szféra hangulatát jelző mutatók vizsgálatával. A tökepiacok a kilencvenes évek óta egyre nagyobb szerepet játszanak a növekedési tényezök közvetítésében. Ami a multinacionális vállalatokat illeti, a kutatás megállapítja: a multik inkább képesek olyan hosszú távú stratégiát kidolgozni, amely nem függ rövidebb távú konjunkturális visszaesésektől. Így a németországi vállalatok erösebb nemzetközi elkötelezettsége immunizáló hatású, csökkenti a nemzetgazdaságok konjunktúraérzékenységét. A kutatók megállapításai 
a politikai elit számára nem voltak túl kedvezőek, hiszen a kormányzat éppen az USA dekonjunktúrájának - a globalizációval erösödö - nemzetközi kihatásaival magyarázta a német gazdaság utóbbi időben tapasztalt gyenge szereplését. A kutatás eredményeit ezért a döntéshozók „kétkedéssel” fogadják.

Visszatérve az EU-USA kapcsolatokhoz, emlékszünk még, hogy az ellentétek felszínre törtek az - egyébként kudarccal zárult - seattle-i WTO fordulón is. A washingtoni kormány akkor elérkezettnek látta az idöt, hogy az USA gazdasági hatalmát éreztetve azokon a területeken érjen el újabb liberalizációs lépéseket, ahol Amerika jóval erősebb vagy versenyképesebb társainál - mint pl. az agrártámogatások vagy a környezetvédelmi és a munkakörülményekkel kapcsolatos kérdések területén -, miközben hallani sem akart arról, hogy kereskedelempolitikájában a leghatásosabb, s egyben partnereik által legtöbbet kifogásolt fegyveréről, a dömpingellenes eljárásokról akár csak tárgyalásokba is bocsátkozzon. Kérlelhetetlen és a saját szempontjait elötérbe helyező álláspontjával aztán nemcsak az Európai Uniót és Japánt fordította maga ellen, hanem a fejlödő országok többségét is.

Hangsúlyozni kell azonban, hogy a két régió kapcsolatának nem ezek a tényezök adják meg az alaptónusát, hanem a csendben, de egyre nagyobb intenzitással zajló transzatlanti fúziós és vállalatfelvásárlási folyamatok, amelyekröl később még lesz szó.

A nemzetközi, világméretủ együttmúködésnek is vannak példái, hiszen egyre érik a felismerés, hogy a globális bizonytalanságot és lassulást csak együttes erövel lehet túlélni. A legfejlettebb ipari államok, a G7 pénzügyminiszterei és jegybankelnökei 2002. április végén rendezett tanácskozásukon új nemzetközi válságkezelő tervben állapodtak meg. A hetek gazdasági vezetői elfogadták az Egyesült Államok által szorgalmazott válságkezelő tervet, melynek értelmében az adós országok csődjének elsösorban rugalmasabb hitelkonstrukciókkal kell elejét venni. Ez a megoldás elmarad a szakértők egy része által kívánatosnak tartott radikális pénzügyi reformoktól, amelyek eleve lehetetlenné tették volna a sok milliárd dolláros nemzetközi mentöakciókat. A G7-féle változat például megállapítja, hogy a csoport kész korlátozni a Nemzetközi Valutaalap (IMF) „tüzoltó” segélyeinek mértékét - eltekintve azoktól az esetektöl, amikor a körülmények kivételt indokolnak. A tanácskozás, amely egybeesett az IMF és a Világbank szokásos tavaszi közgyülésével, kénytelen volt az argentin válság éppen aktuális fordulatával is foglalkozni. Buenos Airesben ugyanis meghatározatlan idöre bezáratták a bankokat, hogy elejét vegyék a lakossági betétek pánikszerủ kivonásának. Az IMF elkötelezte magát a további segélyek mellett de ehhez feltételül szabta, hogy Argentína tervet dolgozzon ki a fenntartható növekedés elérésére.

Vannak persze negatív példák is. A Föld jövöjéröl 2002 szeptemberében Johannesburgban rendezett csúcskonferencián partnerségi javaslattal állt elő az Európai Unió. A tizenötök indítványozták, hogy a fejlödő országokban - az energiakincsek jobb kitermelhetösége érdekében - fogjon össze az állami és magántőke. Az EU szerint így csökkenthetö a szegénység, fejlödhetnek az együttmüködési technikák, és az energetikai piac feltételei kedvezőbbé válhatnának. Az USA gyakorlatilag szabotálta az eseményt, ami nem tett jót a transzatlanti kapcsolatoknak. 
A közös európai valuta bevezetésének hatását illetően megoszlottak a nemzetközi vélemények. Többen a nemzetközi pénzügyek területén konfliktusok kialakulására számítottak az Egyesült Államok és az Európai Unió között. Amiben egyetértés volt: azon túl, hogy eltünik a már hosszú ideje fennálló aszimmetria az amerikai dollár és az EU-országok valutái között, s ennek révén megszünik az utóbbiak sebezhetősége a dollár árfolyamának ingadozásai miatt, az EMU megnöveli Európa hatalmát, befolyását, tárgyalási pozícióit a globális pénzügyi kérdésekben (Dezséri 1999). A közös európai valuta csökkenést okozott a dollár tartalékvaluta-szerepében, és jelentösége a nemzetközi elszámolásokban is növekszik (a kezdeti 33\%-os szintről).

A kamatpolitikák és a két nagy valuta árfolyama szintén gyakran nézeteltérésekhez vezet. Az európai kamatpolitika növekedés-ellenességét sokan, sokszor felrótták már, mondván, hogy az USA-ban $6 \%$ felettiröl $1 \%$-ra vitték le az irányadó kamatot (3. ábra), Japánban pedig gyakorlatilag $0 \%$ a kamat. Igaz ez nem igazán vezetett a japán gazdaság fellendüléséhez, mert a gazdaság strukturális problémái súlyosabbak annál, hogy egy gyógyszer önmagában hatásos legyen. Az európai monetáris politika (vagyis az Európai Központi Bank politikája) tehát folyamatos feszültségforrás az eurooövezet és az Egyesült Államok között. Amerikai részröl rendszeresen vádolják az ECB-t azzal, hogy értelmetlenül ragaszkodik az alacsony infláció fenntartásához, és a kamatszint magasan tartásához, ami megakadályozza a világgazdaságnak a jelenlegi pangásból való kilábalását. Sokak szerint az Európai Központi Bank nem a jelen helyzetnek megfelelő politikát alkalmazza (Zsiday 2002). A kilencvenes évek vége óta egy úgynevezett boom-and-bust ciklust figyelhetünk meg, amikor a nagyon rugalmas kapacitások miatt nem alakul ki túlkereslet, ezért az infláció legfeljebb rövid időre, enyhén jelentkezik, inkább a dezinfláció jellemző. A ciklus így néz ki: növekvő gazdaság; tőkepiaci eufória, ami tovább fokozza a beruházási kedvet; számos gazdasági szegmensben nagy többletkapacitás halmozódik fel; az újabb beruházásokat nem pénzelik; ez komoly leépítésekhez, raktárkészlet-csökkentéshez, elbocsátásokhoz vezet; a gazdaság recesszióba zuhan; a többletkapacitás dezinflációhoz és hosszú ideig tartó lanyha növekedéshez vezet; mihelyst leépülnek a többletkapacitások, elindulhat a gazdasági fellendülés. E rendszerben tehát a többletkapacitás és az infláció hiánya a jellemző. Ebben az új helyzetben a jegybankok feladata sokkal inkább az anticiklikus kamatpolitika megvalósítása, mint az infláció figyelése és annak mindenáron való leszorítása. Kifejezetten magas reálkamatokkal vissza lehet fogni a spekulatív mániát, a túlzott beruházásokat, míg a recessziós időszakban negatív reálkamatokkal csökkenteni lehet a visszaesés mélységét és hosszát.

A kritikák szerint Alan Greenspan, az amerikai jegybank szerepét betöltő Fed elnöke ezt megértette, de Wim Duisenberg és az ECB vezetősége nem, így feláldozzák a növekedést, hosszabbá teszik és elmélyítik a globális recessziót.

Európában az elmúlt időszakban egy újabb potenciális veszélyforrás jelent meg: egy ingatlanár-buborék kialakulása. Számos euró-övezeti országban szárnyalni kezdtek az ingatlanárak, aminek alapvetően a jelentős lakossági megtakarítási szint, az elmúlt évek bizonytalanságai elöl való menekülés és az alacsony hitelkamatok a legfőbb okai. A jelenség, illetve annak tovagyürüző hatásai miatt már az EKB is 
kifejezte aggodalmát. A listavezetők, Franciaország, Spanyolország, Írország és az Egyesült Királyság voltak, ahol 2004-ben legalább 12\%-os volt az áremelkedés.

Az Egyesült Államok gazdasága az utóbbi évtizedben uralta, meghatározta a világ többi gazdaságát, és irányt mutatott azoknak. Az adatok a fejlődő országokat is megszégyenítő termelékenységnövekedésröl és gazdasági bővülésröl tudósítottak. Ennek megfelelően az amerikai vállalati szektor (Corporate America) is az első helyen szerepelt a befektetők listáján. A kitủnő gazdasági teljesítmény záloga az erös dollár volt, ez azonban 2002-ben meredek zuhanásba kezdett. Ez pedig azt jelzi, hogy az amerikai gazdaság nem fogja (nem tudja) kivezetni a világgazdaságot a mostani válságközeli állapotból. Egyben arra is utalhat, hogy az amerikai vállalatok már nem különböznek sem európai, sem pedig japán társaiktól.

Már korábban sokan jósolták, hogy az erős dollár hosszú távon nem tartható fenn. Az Egyesült Államok egyre nagyobb folyó fizetési mérleghiánnyal küszködött, ám ez egy darabig nem jelentett problémát, hiszen azt a külföldiek folyamatosan finanszírozták amerikai eszközök (kötvények, részvények) vételével vagy vállalatfelvásárlással. A folyó fizetési mérleg hiánya azonban a valóságban - mint láttuk - tovább emelkedik. Az amerikai gazdaságba naponta kétmilliárd dollárnak kellene befolynia ahhoz, hogy az ne gyengüljön. A jelek szerint azonban - mivel a dollár 2002 nyarán, egy hónap alatt megközelítőleg 10\%-ot esett az euróval szemben - a tőkebeáramlás mértéke már nem olyan nagy. A befektetők minden bizonnyal felismerték, hogy az amerikai gazdaság a recesszióból kilábalva nem lesz képes a korábbi nagyarányú, 4-5\%-os növekedési ütem elérésére. Az amerikai vállalatok profitkilátásai sem tủnnek már elég jónak ahhoz, hogy érdemes lenne megvásárolni részvényeiket. Egyáltalán nem arról van szó, hogy az amerikai gazdaság romokban hever: csupán látszanak bizonyos jelek, hogy az a fölény, amely a kilencvenes évek második felében és az ezredforduló táján jellemezte azt az európai gazdaságokkal szemben, mára csökken, és megindult egy olyan portfólió-átrendeződés, amelyből leginkább az euró és a japán jen profitálhat.

Az euró árfolyama a dollárral szemben 2004. december 24-én ismét magassági rekordot döntött. A jegyzés már átlépte az 1,35-ös szintet is. Korábban az amerikai elnök és a pénzügyminiszter is jelezte, hogy nem szándékoznak beavatkozni a dollár védelmében, legutóbb pedig a holland pénzügyi tárca vezetỏje közölte, hogy az euró erösödése továbbra is az elfogadható határok között van. Valójában azonban az árfolyam már ",határesetnek" számít, és tetemes károkat okozhat, ha tartósan fennmarad, illetve, ha az amerikai és a japán gazdaság strukturális bizonytalanságai nem enyhülnek.

Az egy hónappal a rekord árfolyam beállta előtt Berlinben rendezett G20 csúcstalálkozón, a résztvevők nem aggódtak különösebben a dollár krónikus gyengélkedése miatt. A Fed elnöke, Alan Greenspan szerint a dollár leértékelődése kívánatos az Egyesült Államok hatalmas folyó fizetési mérleg hiányának megfékezéséhez. A Fed azonban mindenesetre folytatja kamatemelö politikáját (3. ábra): december közepén újabb 25 bázispponttal, 2,25\%-ra emelték az irányadó kamatot, és a Nyíltpiaci Bizottság a jegybanki transzparencia fokozásáról is döntött ${ }^{3}$. 
Marján Attila : Globális verseny a világ jelentös gazdasági blokkjai között.

Tér és Társadalom 19. évf. 2005/1. 21-42. p.

38 Marján Attila

TÉT XIX. évf. 2005

\section{3. ÁBRA}

Amerikai és európai kamatok

(Interest Rates in America and Europe)
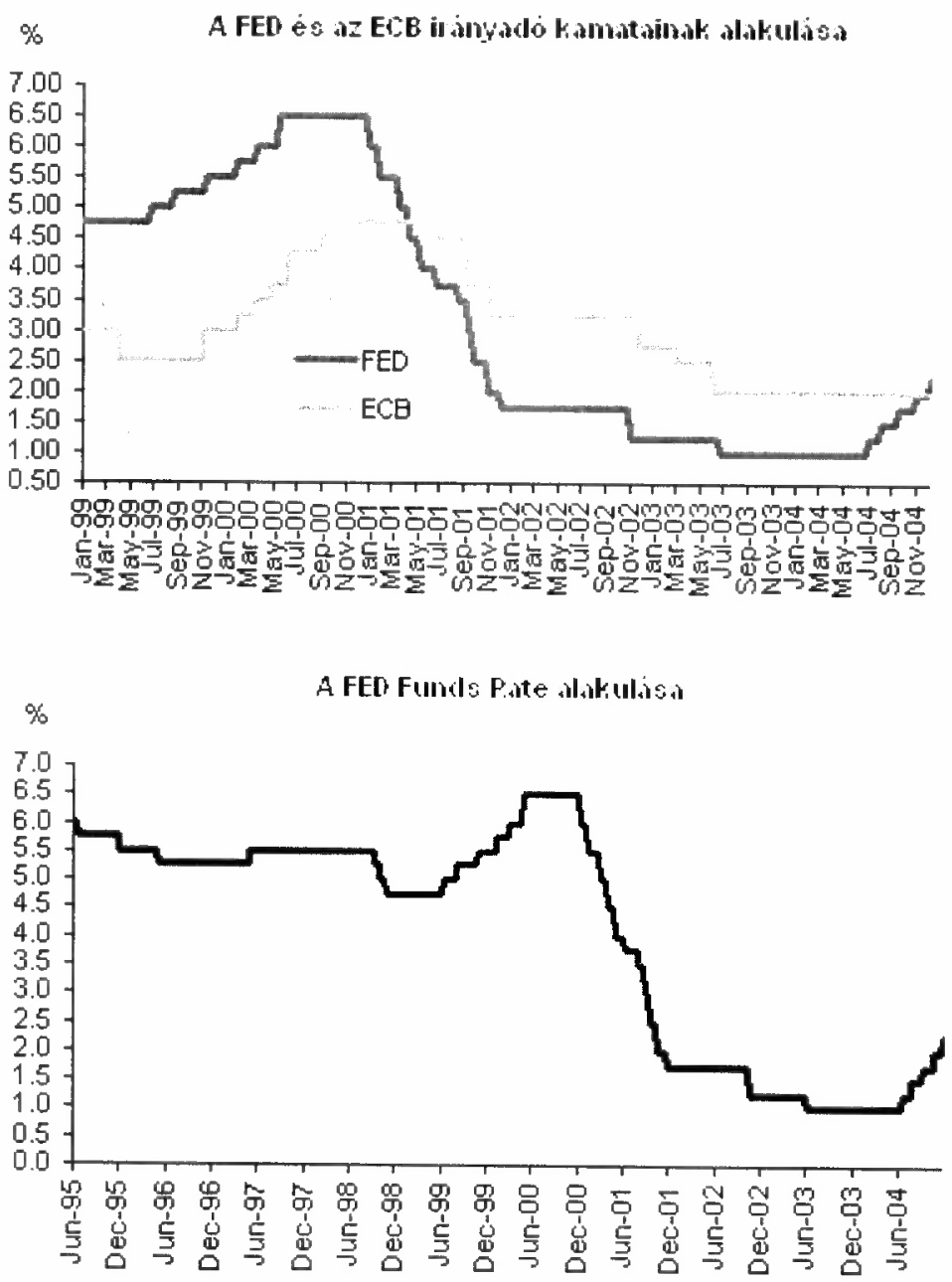

Forrás: Figyelönet.

A gyenge dollár tehát komoly kihívás a világgazdaság számára. A leértékelődés nemcsak az amerikai gazdaság hegemóniájának végét jelezheti, de rámutat arra is, hogy az amerikai gazdaság (belföldi kereslete) önmagában nem lesz elég a globális növekedés beindításához. Az euroövezetnek és Japánnak együtt kell élnie egy erősebb saját devizával, és ez nem fog segíteni a még mindig exportfüggő gazdaságuk talpra állításában. Nem véletlen, hogy az amerikai részvénypiaccal párhuzamosan az európai és a japán tözsdék is mélyrepülésbe kezdtek, ugyanis az indexekben 
komoly súlyt képviselnek az exportáló vállalatok (a Philips, a Nokia, a Volkswagen, a Sony, hogy csak néhányat említsünk). A belsö kereslet terén viszont sem Európából, sem Japánból nem érkeznek kedvező hírek. Ez ugyanakkor megfordulhat, amennyiben a monetáris politika jól alkalmazkodik a megváltozott körülményekhez - vagyis az erősebb saját devizához, és nem emelik meg a kamatlábakat sem.

A globális arénában alapvetöen tehát egy furcsa háromszereplős árfolyampolitikai kötélhúzás alakult ki Európa, Amerika és Ázsia között, melynek során az USA olyan hatalmas fizetési hiányt halmozott fel a másik két féllel szemben, hogy az már a világméretü stabilitás szempontjából is problematikusnak minősíthető. Föleg akkor, ha a nemzetközi befektetök végleg kiábrándulnának a dollárból, és menekülnének dollár-portfoliójuktól. A helyzet megoldására több ötlet is felmerült. Az elsőt az amerikaiak és az európaiak javasolták: Ázsia (főleg Kína) engedje valutáinak felértékelödését. A másik javaslat főképp Ázsia és Európa részéröl az, hogy az USA csökkentse radikálisan költségvetési hiányát, hiszen egy olyan időszakban, amikor a hazai megtakarítások történelmi mélyponton vannak, a költségvetési hiány egyértelmüen külső instabilitást is eredményez. A harmadik, európaiak által felvetett elképzelés pedig az, hogy az EKB avatkozzon be a piacon, megelőzendő a dollár további zuhanását. Egyik javaslat sem könnyen megvalósítható, hiszen az ázsiai országok között nincsen árfolyampolitikai koordináció, ezért egyikük sem fog lépni, mivel attól tart, hogy ha a többiek nem követik, súlyos versenyhátrányba kerül. Az USA deficitcsökkentése pedig kétséges a nagyszabású adócsökkentési program miatt, valamint a jól ismert politika miatt, ami így szól: „,a dollár amerikai valuta, de

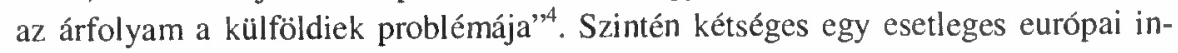
tervenció eredményessége, hiszen az amerikai fizetési mérleg-hiány jelentős mértékben Ázsiával és nem Európával szemben áll fenn. Ráadásul mindegyik régió attól fél, hogy a másik kettő összefogva kijátssza őt, ami tovább élezi a helyzetet. Európa egy ázsiai-amerikai hallgatólagos összefogástól tart, amely során de facto egy dollárblokk alakul ki Ázsiában, és az sem teszi az öreg kontinenst boldoggá, hogy az ázsiaiak egyre több dollárt vásárolnak fel. Ázsia viszont attól tart, hogy Amerika összefog Európával, és rákényszeríti őket valutáik felértékelésére. Az amerikaiak pedig legfőképp attól tartanak, hogy az ázsiaiak elkezdik átváltani dollárjukat euróra. A helyzet tehát igen nehéz, és megoldása feladja a leckét a gazdasági szakembereknek és a politikusoknak egyaránt.

A nemzetközi árfolyamok újrarendezése mindenesetre el kerülhetetlennek látszott 2005 elején. Kérdéses volt azonban az, hogy ezt hogyan lehetne megtenni egy nagy nemzetközi pénzügyi válság elkerülésével. Egyesek, reménytelennek látva az amerikai-európai koordinációt, az euró és a jen közötti fokozottabb együttmüködést szorgalmazták. Az amerikai deficitet Európa, Kína, Japán és a többi kisebb keletázsiai ország finanszírozza, és míg az amerikai háztartások alig tartalékolnak, addig a japán és európai háztartások túl sokat tesznek félre. (Az ázsiai valuták általános erösödése alapvetően annak volt köszönhetö, hogy a világ számolatlanul öntötte a pénzt az ázsiai tőkepiacokba, megcsapolandó a hihetetlen ütemü kínai növekedést.) 
Marján Attila : Globális verseny a világ jelentős gazdasági blokkjai között.

Tér és Társadalom 19. évf. 2005/1. 21-42. p.

Hogyan lehetne ezt az anomáliát kezelni? Például úgy, hogy az amerikai háztartások kevesebbet költenének és többet takarítanának meg. Ez azonban nem valószínü, hiszen a tőzsdei befektetések még mindig jóval jövedelmezőbbek, mint a bankbetétek.

Emellett a csökkenő amerikai kereslet csökkentené az európai exportot is, ami az öreg kontinensen a szerény mértékü fejlődés alapja. Vagyis, az amerikai keresletcsökkenésnek európai keresletnövekedéssel kell párosulnia. A másik megoldás a dollár leértékelése lenne, de azt látjuk, hogy a drámai árfolyammozgások ellenére az euró-dollár effektív árfolyam csak minimális mértékben (5\%) értékelödött le. Számos, dollárhoz kötött valuta van a világgazdaságban, ezért a teher azokon a valutákon van, amelyek szabadon lebegnek a dollárhoz képest, mint az euró és a jen. Amerika rugalmasabb árfolyampolitikát kért Kínától, de az árfolyam felszabadítása valószínủleg egy új ázsiai válsághoz vezetne, és lássuk be, Kína sikere a globális integrálódásban alapvetően stabil és alulértékelt valutájának köszönhetö. De ne feledkezzünk meg arról a tényröl - miközben mindenki a dollárárfolyamra koncentrál -, hogy a kínai export 25\%-a, az import 10\%-a kapcsolódik Európához, míg az USA-hoz csak $20 \%$, illetve $8 \%$ ! Miért olyan fontos mégis a dollár? Alapvetỏen azért, mert az ázsiai országok mindegyike erősen kötödik a dollárhoz, ami a regionális kereskedelem valutájának számít, és ezen országok számára a regionális kereskedelem fontosabb, mint az USA-, vagy az EU-kereskedelem. Vagyis egy rugalmasabb dollárárfolyam destabilizálhatná a regionális gazdaságot. Tehát a megoldás az USA és az eurózóna közötti nagyobb stabilitás és jobb koordináció lenne. Európa mellett Japánnak is érdeke lenne a dollár leértékelödésének megállítása, ezért felmerülhet a két központi bank intervenciós politikájának koordinálása, Kína pedig egy, az eurót és a jent nagyobb súllyal szerepeltető kosárhoz köthetné a valutáját.

Itt tennék említést röviden Michael Ehrmann és Marcel Fratzscher (2002) kiváló tanulmányának megállapításairól. Ök 2002 decemberében publikált munkájukban azt vizsgálták, hogy a Monetáris Unió bevezetése növelte-e az eurórégió és az Egyesült Államok, illetve elsösorban azok pénzpiacai kölcsönös függésének mértékét. Két időszakot vetettek össze: egyrészt az 1993 és 1998 közötti, másrészt az 1999 és 2002 közötti periódust, és megvizsgálták, hogy az USA és Németország, illetooleg 1999 után az USA és az eurórégió piaci fejleményei, illetve makrogazdasági hírei mennyiben befolyásolták a másik régió pénzügyi piacait. Megállapítják, hogy az EMU létrejötte fokozta az eurórégió piaci fejleményeinek az USA-ra való hatását. Igaz azonban, hogy az európai piacok még mindig élénkebben reagálnak az amerikai fejleményekre, mint fordítva. Különösen nagy jelentőségük volt az európai piacok számára az amerikai makrogazdasági bejelentéseknek az EMU indulása idején és a 2001-es válság idején. Ennek az a magyarázata, hogy ezekben az időkben különösen nagy volt a piaci bizonytalanság Európában. Az EMU létrejötte után az európai piacoknak ki kellett tapasztalniuk az újonnan felállított Európai Központi Bank monetáris politikájának müködését, és amíg ez a tanulási folyamat tartott, érezhetöen bizonytalanabbak voltak a piaci szereplök.

Összefoglalva: elöretekintve elmondható, hogy az Egyesült Államok és az EU közötti kapcsolatok intenzitása minden bizonnyal erösödni fog, mivel - részben az EU 
relatív súlyának növekedése miatt is - egyre kevesebb nemzetközi probléma oldható meg transzatlanti együttmüködés és megegyezés nélkül.

Az együttmúködés jövőjéröl különböző elképzelések léteznek a Transzatlanti Szabadkereskedelmi Megállapodástól (TAFTA) kezdve az Atlanti Közösség gondolatáig. Vannak - számomra reálisabbnak tünő - elképzelések (pl. a „fine tuning” stratégia), amelyek a meglévő kapcsolatrendszert módosítanák, fejlesztenék tovább. Más elképzelések szerint az Egyesült Államok és az EU közötti együttmüködés alapvetö elmélyítése és kibövítése a cél. Egy neves szakértőkböl álló munkacsoport pédául 2005 februárjában, Bush elnök európai látogatása előtt tette közzé a „Megállapodás az Egyesült Államok és Európa között" címủ dokumentumot, amely konkrét politikai javaslatokat tartalmaz a transzatlanti kapcsolatok javítására. A dokumentum kitér a legfontosabb stratégiai kihívásokra, hitet téve amellett, hogy még a legnehezebb esetekben is lehet átfogó transzatlanti stratégiát kovácsolni. Az Európa és az USA közötti partnerség megújítandó, de ehhez tettekre és jószándékra van szükség, elsősorban a nagy globális kérdéskörök területén. Barroso bizottsági elnök a nagy jelentőségü látogatás elött elmondta: azt szeretné, ha a vizit helyreállítaná a transzatlanti kapcsolatokat, amelyek félreértésektöl, elöítéletektöl és sztereotípiáktól voltak terhessek a látogatást megelöző években. Reményét fejezte ki, hogy az amerikaiak úgy tekintenek majd Európára, mint egy igazi globális partnerre.

\section{Jegyzetek}

' A kínai kormány 2005-re 8\%-os GDP-növekedést céloz meg a 2004-es, várhatóan 9\% feletti növekedési ütem után. A kínaiak hivatalosan már évek óta 7\% körüli GDP-növekedési célt fogalmaznak meg, melyet rendre túllépnek, így azok hitelessége erösen korlátozott volt. A kínai kabinet már közel egy éve számos intézkedéssel (pl. bankok tartalékrátájának emelése, bizonyos építési beruházások megtiltása, stb.) azt kívánja elérni, hogy a gazdaság növekedési üteme fokozatosan mérséklődjön és elkerüljék a túlhevülést.

2 www.zew.de: MTI-Eco, 2002. június 25.

${ }^{3}$ A Nyíltpiaci Bizottság a jegybanki transzparencia fokozásának céljával arról is döntött, hogy ezentúl a kamatdöntésekröl készített rövidített jegyzökönyvet (minutes) a döntést követö 3 héten belül nyilvánosságra hozza, szemben a korábbi gyakorlatban megszokott 6 hetes csúszással.

${ }^{4}$ John Conally, John F. Kennedy pénzügyminiszterének mondása.

\section{Irodalom}

Dezséri K. (1999) Transzatlanti versengés. - Közgazdasági Szemle. Május.

Dorrucci, E.-Firpo, S.-Fratzscher, M.-Mongelli, F.P. (2002) European integration: what lessons for other regions? The case of Latin America, - ECB Working Paper. 185. Október. Frankfurt.

Ehrmann, M.-Fratzscher, M. (2002) Interdependence between the euro area and the US: what role for the EMU? - ECB Working Paper. 200. December. Frankfurt.

European Commission, Forward Studies Unit (1999) Scenarios for Europe 2010. Working Paper. Július. Brüsszel.

European Commission services DG Ecfin (2002) Responses to challenges of globalisation - A study on the international monetary and financial system and on financing for development. Brüsszel.

Fratzscher, M. (2002) The Euro bloc, the Dollar bloc and the Yen bloc: how much monetary policy independence can exchange rate flexibility buy in an interdependent world? - ECB Working Paper. 154. Június. Frankfurt.

Marján A. (2004) Euró pénzïgyek, globalizáció. Savaria University Press, Szombathely. 
Marján Attila : Globális verseny a világ jelentös gazdasági blokkjai között.

Tér és Társadalom 19. évf. 2005/1. 21-42. p.

Sutherland, A. (2002) International monetary policy coordination and financial market integration. ECB Working Paper. 174. Szeptember. Frankfurt.

Wolf, M. (2005) Comment and analysis - Why do English-speaking countries perform better? Financial Times. Január 25. 36. o.

Zsiday V. (2002) Az utolsó kereszteslovag. - HVG. November 7.60. o.

\title{
GLOBAL COMPETITION AMONG THE IMPORTANT ECONOMIC BLOCKS
}

\begin{abstract}
ATTILA MARJÁN
The last few decades marked a significant intensification of the global competition between the different economic superpowers of the world and also have brought about the emerging of new contestants in the international arena, such a China or India. Not only competition increased but the global interdependence (or globalisation) has developed at an unprecedented pace too. It is not surprising therefore that nowadays economic super-blocs are setting competitiveness as their primary policy objective. The different blocs seem to have different problems though: there is nothing wrong with the US growth or employment figures, though the ever-growing twin-deficit is threatening the economic outlook overseas driving the dollar to historic lows that hampers the recovery of European industry which is still heavily export-driven. Europe suffers from insufficient growth and weak domestic demand, Japan is in stagflation for years. China on the other hand has difficulties with controlling its wild economic growth and the growing international pressure to readjust its extremely undervalued exchange rate. Who will prevail with what sort of a policy mix, only time will tell, but odds are certainly not proportionally distributed amongst the parties. One thing is certain: Europe - seeking for higher growth and better competitiveness, while trying to preserve its special economic model, and faced by a dramatically ageing population - must do its utmost to keep up the pace.
\end{abstract}

